\title{
Emotional Support and the Teaching of Science and Literature: Contribution to Educational Methodologies in the Preschool Context
}

\author{
Felipe Mauricio Pino Perdomo \\ Minuto de Dios University Corporation \\ Jhon Edwin Trujillo Paredes \\ Minuto de Dios University Corporation
}

\begin{abstract}
This document seeks to demonstrate the need to address the educational context of preschool education from the dynamics of Early Childhood Education and Psychology, two areas of training and knowledge of the Minuto de Dios University Corporation. A qualitative case study type design was proposed from the perspective of educational action research working with two preschool grades, one in a public context and the other in a private context. In the initial identification phase, a contextualization of the trends in literature and natural sciences in early childhood education was carried out based on a documentary review; in the phase of recognition based on the discovery and analysis of the facts, the The Classroom Assessment Scoring System (CLASS) instrument was applied to evaluate the level of emotional support provided by the teachers to their students during the teaching process. Finally, in the formulation phase of the general plan, didactic strategies for the development and promotion of literature and the teaching of natural sciences in early childhood education were proposed.
\end{abstract}

Keywords: early childhood education, Science education, literacy education, emotional support

\section{PROBLEM STATEMENT AND BACKGROUND}

In the current training processes in undergraduate programs at the international and national levels, conceptual and structural changes are evident in the professional component. A discussion of didactics necessarily involves a reflection on the processes that make it possible to make knowledge real for learners and, specifically, when early childhood education is involved. This panorama shows how decisive the pedagogical proposals must be in order to promote contents articulated to the educational needs of each of the training contexts in Colombia, which, from the Ministry of National Education [MNE] contemplates state guidelines for training in science, literature, art and play. However, the training components in preschool and the current didactic trends seem to be disjointed from the realities or in other cases completely unknown by child trainers since they only represent an itinerary present in the subject plans, but absent from the reality of the classroom because the design of environments that develop art, play, literature and science, as requested from the preschool curricular guidelines presented by the MNE, do not include the new didactic trends for the effective development of knowledge in this educational population. In this regard, it has been found that interventions aimed at adult caregivers of children between zero and six years 
of age can have an impact on the development of social capital in communities, making them relevant strategies to overcome poverty (Knudsen, Heckman, Cameron y Shonkoff, 2006).

It is important to point out that the first years of children's lives are a time of great changes that will have repercussions throughout their lives, so that the decisions taken to guarantee their rights will influence the progress of a country; however, initial care is still incipient in several parts of the world, and children continue to be the main victims. For UNICEF, children's experiences during their early years will depend, to a large extent, on the interactions they establish with mothers, fathers, family members and other adults such as teachers. Along these lines, in Colombia, the technical referents for early and preschool education in the framework of the comprehensive care of the public policy from Zero to Forever (2017), conceive the child as a unique subject that is not limited to receiving information, so their development should be understood under a multidimensional view. These referents have been nurtured by various studies in education and neurodevelopment that affirm that the relationships that children establish with adults influence their brain structuring, even from the prenatal stage. Therefore, teachers and adults in general play a mediating role, which allows them to understand child development and from there to enhance it. From the attachment theory it has been pointed out that the classroom constitutes a protective environment, which depends on the type of interactions that the adult establishes with the child (Berlin and Cassidy. 1999), that is to say that caregivers (parents, teachers, among others), through the type of interactions they promote, prevent children from presenting behaviors such as withdrawal and emotional immaturity, nervousness, rejection of people, apathy, motor and language difficulties, academic difficulties, among others.

In Colombia, it was identified that to date there are very few studies and investigations that focus their interest on the cognitive and affective interactions between adults and children in the classroom, taking record of places such as Bogotá, Cúcuta, and Ibagué where the implementation of innovative strategies has begun, which have had satisfactory and significant results, among which stand out activities such as games and children's readings, which are taught and directed under a constructivist perspective, leaving aside the traditional models (Duque and Ovalle 2011). Therefore, it is appropriate to identify intervention alternatives that increase the quality of interactions provided by adults in the classroom, since UNICEF (2016) has reaffirmed the effectiveness of interventions aimed at educational agents for the promotion of healthy development in children. This organization expresses the urgency of designing and implementing strategies framed under the advances of public policies on infancy and childhood, which will enable the improvement of the quality of care, teaching and attention practices in the classroom, favoring an equitable and stimulating education.

\section{METHODOLOGY}

A qualitative case study approach design was proposed from the perspective of educational action research. Accordingly, from the perspective of educational research, action research is characterized as a variant of evaluative research aimed at solving a specific problem in a specific place (MacMillan and Schumacher, 2010, p.26). Action research framed to the present research is characterized by the generation of general prescriptive proposals that need to be put into practice, the diagnosis and accurate understanding of the specific problem, the practical action aimed at change, the finding of relationships through concrete description and the application of research from external researchers (Parra, 2009).

\section{Population}

Corresponds to teachers, and to children between the ages of 5 and 6 years old in the preschool stage, in the José Joaquín Flórez (public) and Rafael García Herreros (private) educational institutions.

\section{Sample}

The Classroom Assessment Scoring System (CLASS) instrument was applied at the José Joaquín Flórez educational institution (public), with 23 children and one regular teacher, and at the Rafael García Herreros institution (private), with 19 children, one assistant and one regular teacher. 


\section{Methodological Design}

Action research is characterized by redirecting the educational process to the improvement of educational practice, giving priority to the process and reflecting on the result. Thus, the process was structured in a cyclical way, having as phases the identification of the initial idea, the recognition based on the discovery and analysis of the facts, the formulation of the general plan, the implementation of the actions and the subsequent review of the results (Elliot, 2005).

In the initial identification phase, a contextualization of the trends in literature and natural sciences in early childhood education was carried out based on a documentary review.

In the phase of Recognition based on the discovery and analysis of facts, the CLASS instrument was applied to evaluate the level of emotional support provided by teachers to their students during the teaching process. A comparison was made between the discourse and the actions of a teacher with affinity to teacherstudent relationships in the preschool grade. It was carried out from a qualitative point of view with a comparison study between a private school and an official (public) school. We worked with teachers with a total of 18 and 23 students respectively in the preschool classrooms. The children are between 4 and 5 years old, belonging to the José Joaquín Flórez de Hernández Educational Institution and the Rafael García Herreros Mixed High School in the city of Ibagué (Colombia). Observations of a class were made at the beginning of the school year, respectively, to observe the differences and similarities of the teachers of the two territorial entities in their relations with the students. The classrooms were filmed for 60.49 and 40.84 minutes each.

The CLASS instrument contemplates a rating scale in ranges from 0 to 7 points, the scores are assigned in accordance with the indicators that make up the dimensions: positive climate, negative climate, teacher sensitivity and consideration of the student's perspective. The score obtained by each teacher is placed according to performance level: low $(1,2)$, medium $(3,4,5)$ or high $(6,7)$. Therefore, the analysis of the information was carried out within the framework of the established domains, dimensions and rating ranges.

Finally, in the formulation phase of the general plan, didactic strategies for the development and promotion of literature and the teaching of natural sciences in early childhood education were proposed.

\section{RESULTS}

Phase 1. I

Initial Identification and Document Review Science and Early Childhood Education

TABLE 1

DOCUMENTARY REVIEW RESULTS

\begin{tabular}{|l|l|l|}
\hline Year & Revised & Endorsed \\
\hline $\mathbf{2 0 1 6}$ & 25 & 7 \\
\hline $\mathbf{2 0 1 7}$ & 48 & 30 \\
\hline $\mathbf{2 0 1 8}$ & 28 & 9 \\
\hline $\mathbf{2 0 1 9}$ & 21 & 5 \\
\hline Total & $\mathbf{1 2 2}$ & $\mathbf{5 1}$ \\
\hline
\end{tabular}

At the level of necessities, a low scientific literacy was found, accompanied by a low level of academic literature, evidencing the need to contribute to scientific learning, overcoming traditional, instrumental and reductionist models of science teaching. There was also little interest in learning in contexts taking advantage of experiential activities, lacking the practical use of what was learned for the student, decreasing the discovery and autonomous processes and directed to unidirectional models. At the level of trends and proposals, learning accompanied by early and contextualized stimulation processes that allow defining and conceptualizing phenomena of the natural world was found. In turn, the characterization of children's scientific thinking allows the use of symbolic representations of infants to appropriate scientific knowledge. 
Learning based on motivation, experience, inquiry and the proposal of alternative ideas to arrive at explanations of phenomena also appears as a strong proposal in the literature. Critical reflection is also wielded as a complementary alternative to the processes of child experimentation in controlled environments, fostering attitudes aimed at understanding the world around them.

\section{Phase 1. Initial Identification}

Initial Identification and Document Review Literature and Early Childhood Education

TABLE 2

DOCUMENTARY REVIEW RESULTS

\begin{tabular}{|l|l|l|}
\hline Year & Revised & Endorsed \\
\hline $\mathbf{2 0 1 6}$ & 17 & 12 \\
\hline $\mathbf{2 0 1 7}$ & 22 & 19 \\
\hline $\mathbf{2 0 1 8}$ & 32 & 17 \\
\hline $\mathbf{2 0 1 9}$ & 35 & 22 \\
\hline Total & $\mathbf{1 0 6}$ & $\mathbf{7 0}$ \\
\hline
\end{tabular}

Following the documentary search that included a review of 3 years (2016-2019) of academic production on the topics and problems of teaching children's literature, it was noticed that there is a considerable number of documents that deal with this educational phenomenon from different methodological perspectives, from those that still consider literature as a teaching tool, and others that take the literary text as the basis for carrying out the educational act. Thus, the amount of production is encouraging because the topic is highly relevant, however, it is necessary to look at its content, because in this production an encyclopedic posture could be evidenced, a situation that is not bad in itself, because the dialogue with the theoretical tradition will always be necessary to give that academic character to the writing, even so, when writing is limited to commenting on already canonical approaches, the discourse feels exhausted, but above all, outdated, all because there is no evidence of a strong position, why not say it, paradigmatic in the teaching of literary art in children. In addition to the above, it is necessary to include that literature is not taught in preschool education, this process takes place in higher education scenarios, where the study of the literary work is given from a context governed by theoretical rules; what preschool seeks is to value the aesthetic notion of the text, that which, in the words of Alfonso Cárdenas Páez (2005) seeks to make man more human. The documentary review also showed a panorama of didactic order, all because there is a concern about doing with knowledge, an interesting notion that must be accompanied by rethinking the canonical notion as indicated above, this to the extent that didactics wonders about the formative processes in the classroom, processes that value how to teach, but also what is taught, the latter criterion alludes to the canonical, to the necessary updating of readings, themes and events from the context of children's literature.

\section{Phase 2. Recognition Based on Factual Discovery and Analysis}

Two observation visits were made to the private sector institution Liceo Mixto Rafael García Herreros, where the teacher M.P. was observed. For the observation of the class, she used the methodology of division by subjects, first the literature/language area and then the Science class.

At the same time, two observation visits were made to the José Joaquín Flórez de Hernández public school in Picaleña, where the teacher L.Z. carried out a transversal planning in which she involved several educational contents such as: literature-language, mathematics, science and art. The observation of the positive and negative climate was carried out. 
TABLE 3

CLASS RESULTS PRIVATE INSTITUTION: SCIENCE CLASS

\begin{tabular}{|c|c|c|}
\hline \multirow[t]{4}{*}{$\begin{array}{l}\text { Positive } \\
\text { climate }\end{array}$} & Relationship & $\begin{array}{l}\text { There is a positive relationship with the students, there is a somewhat } \\
\text { limited affective relationship with the children, only pedagogical } \\
\text { interaction when required (difficulty in the activity, interaction with their } \\
\text { peers), calling them by name and sometimes calling them with affectionate } \\
\text { words, it should be noted that the teacher feels comfortable with the work } \\
\text { she performs on a daily basis. }\end{array}$ \\
\hline & Positive affect & $\begin{array}{l}\text { Slightly affectionate with their students, involved in the activity, keeping } \\
\text { a certain distance, not showing preference with any of their students, in the } \\
\text { same way it was possible to visualize that some of the children do not feel } \\
\text { comfortable in the classroom, others lose connection with it and on } \\
\text { repeated occasions demands the attention of students. }\end{array}$ \\
\hline & $\begin{array}{l}\text { Positive } \\
\text { communication }\end{array}$ & $\begin{array}{l}\text { Good classroom management promotes participation, reinforces positively } \\
\text { when activities are performed correctly, incorporates the children's } \\
\text { opinions into the class, recognizes the children's work, explains activities } \\
\text { clearly and harmoniously. }\end{array}$ \\
\hline & Respect & $\begin{array}{l}\text { Reciprocal respect, does not allow nicknames between them and to speak } \\
\text { students must ask for participation. The teacher is respectful when } \\
\text { demanding attention and speaks clearly. }\end{array}$ \\
\hline \multirow[t]{2}{*}{$\begin{array}{l}\text { Negative } \\
\text { climate }\end{array}$} & Negative affect & $\begin{array}{l}\text { There is no evidence of displeasure in expressions or unkind looks or } \\
\text { expressions of negativity. The teacher's posture towards children is neutral } \\
\text { and handles situations of disrespect among children in an appropriate } \\
\text { manner. It is evident that the teacher is slightly cold with the children, there } \\
\text { is affectionate contact, constantly reminding the students how to behave } \\
\text { and sometimes not allowing them to explore the activity they are engaged } \\
\text { in. }\end{array}$ \\
\hline & $\begin{array}{l}\text { Response } \\
\text { capacity }\end{array}$ & $\begin{array}{l}\text { There is no evidence of bad language or derogatory looks, some of the } \\
\text { students do not feel comfortable in class, they lose the connecting thread } \\
\text { easily, in no case is anger shown, they do not shout or threaten to establish } \\
\text { order or to enforce the activity. }\end{array}$ \\
\hline $\begin{array}{l}\text { Teacher } \\
\text { sensitivity }\end{array}$ & & $\begin{array}{l}\text { At times the teacher is aware of the needs of students who need extra help, } \\
\text { assistance or attention; she works with those who are connected to the } \\
\text { activity and does not delay the activity for those who are not working; the } \\
\text { teacher is responsive and supports the group but not the individual; few } \\
\text { students feel uncomfortable or lose focus of the activities they have } \\
\text { programmed. }\end{array}$ \\
\hline \multirow[t]{4}{*}{$\begin{array}{l}\text { Addressing } \\
\text { the } \\
\text { student's } \\
\text { perspective }\end{array}$} & $\begin{array}{l}\text { Flexibility and } \\
\text { student focus }\end{array}$ & $\begin{array}{l}\text { Motivates students to express their ideas, shows interest in some of them } \\
\text { and sometimes incorporates some of them in the activities. When } \\
\text { conducting the science workshop, clearly explains the activity, does not } \\
\text { allow exploration within the work group. }\end{array}$ \\
\hline & $\begin{array}{l}\text { Autonomy and } \\
\text { leadership } \\
\text { support }\end{array}$ & $\begin{array}{l}\text { The intervention in the area allowed the children to choose the story of } \\
\text { their preference, choosing one at random, does not give responsibility to } \\
\text { their students or motivate them to be class leaders. }\end{array}$ \\
\hline & $\begin{array}{l}\text { Student } \\
\text { expression }\end{array}$ & $\begin{array}{l}\text { Motivates students to participate through open-ended questions, so they } \\
\text { can express their ideas and create their own concepts, in some cases they } \\
\text { participate actively. }\end{array}$ \\
\hline & $\begin{array}{l}\text { Restriction of } \\
\text { movement }\end{array}$ & $\begin{array}{l}\text { The teacher was constant in the restriction of movements, always making } \\
\text { calls of attention asking the students to sit down or to pay attention, the } \\
\text { teacher did little to encourage autonomy and leadership, being the one in } \\
\text { control. }\end{array}$ \\
\hline
\end{tabular}


TABLE 4

CLASS RESULTS PUBLIC INSTITUTION: SCIENCE CLASS

\begin{tabular}{|c|c|c|}
\hline \multirow[t]{4}{*}{$\begin{array}{l}\text { Positive } \\
\text { climate }\end{array}$} & Relationship & $\begin{array}{l}\text { Positive relationship with students, limited to a teacher-student } \\
\text { relationship, generates trust, has a sense of humor without losing the } \\
\text { seriousness of the class, incorporates processes of imagination, } \\
\text { assimilation of the contents addressed in class, a pleasant emotional } \\
\text { climate is perceived, motivates students to participate and incorporates } \\
\text { their ideas into the activity. }\end{array}$ \\
\hline & Positive affect & $\begin{array}{l}\text { Responds to the children's concerns with kindness, no shouting or } \\
\text { reproachful words are heard, on occasions reflects support to the } \\
\text { students when they require it, it is evident that the children enjoy their } \\
\text { class, actively participate in it, shows enthusiasm in the development, } \\
\text { participatory class. }\end{array}$ \\
\hline & $\begin{array}{l}\text { Positive } \\
\text { communication }\end{array}$ & $\begin{array}{l}\text { Good classroom management and motivates students to perform the } \\
\text { activities, praises with empowering words, students are attentive in the } \\
\text { development of the class and are participatory, good management of } \\
\text { resources and allows children to give their ideas and incorporates them } \\
\text { in constant feedback. }\end{array}$ \\
\hline & Respect & $\begin{array}{l}\text { Great teacher-student respect, from the beginning the rules are made } \\
\text { clear and are recognized, when any of them addresses the teacher or } \\
\text { makes a contribution to the class, the teacher attends to them looking } \\
\text { at their face, in the same way the classmates pay attention, the ideas of } \\
\text { others are respected, it was recorded that nicknames or teasing towards } \\
\text { classmates are not allowed, when a situation like this occurs the teacher } \\
\text { corrects the event in a different way being fair. }\end{array}$ \\
\hline \multirow[t]{4}{*}{$\begin{array}{l}\text { Negative } \\
\text { climate }\end{array}$} & Negative affect & $\begin{array}{l}\text { There was no anger or displeasure, always had a neutral, friendly and } \\
\text { cordial posture, a situation of disrespect was handled in a pleasant way, } \\
\text { trying to make everyone understand that such action was not well seen } \\
\text { in the class. }\end{array}$ \\
\hline & $\begin{array}{l}\text { Sarcasm and } \\
\text { respect }\end{array}$ & $\begin{array}{l}\text { Did not use sarcastic or humiliating words with the students, handled } \\
\text { conflict situations or situations of concern in a calm, serene and } \\
\text { respectful manner, attending to the needs of the students, a calm and } \\
\text { pleasant classroom climate was perceived. }\end{array}$ \\
\hline & $\begin{array}{l}\text { Punitive } \\
\text { control }\end{array}$ & $\begin{array}{l}\text { Positive student climate, receptive and participative, the teacher used } \\
\text { an appropriate tone of voice during the course of the activity, being } \\
\text { very natural in the development of the activity, not exerting control } \\
\text { with threats or punishments. }\end{array}$ \\
\hline & $\begin{array}{l}\text { Severe } \\
\text { negativity }\end{array}$ & $\begin{array}{l}\text { The educator does not use physical punishment or intimidation with } \\
\text { any of the students, and always reflects support and confidence in the } \\
\text { activities. }\end{array}$ \\
\hline $\begin{array}{l}\text { Teacher } \\
\text { sensitivity }\end{array}$ & & $\begin{array}{l}\text { Attends to students' difficulties in a friendly manner, makes them feel } \\
\text { comfortable in the classroom, provides support when they encounter } \\
\text { difficulties, allows them to participate and express their ideas, resolves } \\
\text { difficulties in an appropriate manner. }\end{array}$ \\
\hline
\end{tabular}




\begin{tabular}{|c|c|c|}
\hline \multirow{4}{*}{$\begin{array}{l}\text { Addressing } \\
\text { the } \\
\text { student's } \\
\text { perspective }\end{array}$} & $\begin{array}{l}\text { Flexibility and } \\
\text { student focus }\end{array}$ & $\begin{array}{l}\text { Incorporates students' ideas into the activity, is flexible in the face of } \\
\text { difficult situations, is attentive to changes that arise in the activity.. }\end{array}$ \\
\hline & $\begin{array}{l}\text { Autonomy and } \\
\text { leadership } \\
\text { support }\end{array}$ & $\begin{array}{l}\text { Creates environments of autonomy in the activities allowing children } \\
\text { to explore and create their own concepts, motivates them to work and } \\
\text { some of the students show themselves as group leaders. }\end{array}$ \\
\hline & $\begin{array}{l}\text { Student } \\
\text { expression }\end{array}$ & $\begin{array}{l}\text { Students can express their thoughts freely and in an orderly manner, } \\
\text { motivates them by generating ideas and questions, is in constant } \\
\text { interaction with them. }\end{array}$ \\
\hline & $\begin{array}{l}\text { Restriction of } \\
\text { movement }\end{array}$ & $\begin{array}{l}\text { It is not a rigid class, the children have ease of movement, these are } \\
\text { orderly and in accordance with the activity. It generates a motivating } \\
\text { and meaningful activity. }\end{array}$ \\
\hline
\end{tabular}

TABLE 5

CLASS RESULTS PUBLIC INSTITUTION: LITERATURE CLASS

\begin{tabular}{|c|c|c|}
\hline \multirow[t]{4}{*}{$\begin{array}{l}\text { Positive } \\
\text { climate }\end{array}$} & Relationship & $\begin{array}{l}\text { The teacher shows a little more physical contact with the children, } \\
\text { although it is not very strong and constant. There is no preference with } \\
\text { any of the students; in the realization of the reading activity; there was } \\
\text { evidence of tiredness in some of the students in the proposed activity, } \\
\text { getting distracted very easily, although this is not present in all of them. }\end{array}$ \\
\hline & Positive affect & $\begin{array}{l}\text { Absence of affection and smiles with the students, aimed at fairness. } \\
\text { Students enjoy their class and participate actively. The teacher shows } \\
\text { enthusiasm in the development of the class. }\end{array}$ \\
\hline & $\begin{array}{l}\text { Positive } \\
\text { communication }\end{array}$ & $\begin{array}{l}\text { Good classroom management focused on motivation and development of } \\
\text { the activities proposed by the teacher, constant praise and attention and } \\
\text { participatory development. }\end{array}$ \\
\hline & Respect & $\begin{array}{l}\text { Respect for the students, maintains eye contact when answering } \\
\text { questions, students pay attention. It was evident that nicknames or teasing } \\
\text { of classmates are not allowed, relevant corrections in intensity, frequency } \\
\text { and time always with a pedagogical approach. }\end{array}$ \\
\hline \multirow[t]{4}{*}{$\begin{array}{l}\text { Negative } \\
\text { climate }\end{array}$} & Negative affect & $\begin{array}{l}\text { It was not observed that the teacher showed anger or displeasure at any } \\
\text { time, on the contrary, the teacher always had a neutral position, handling } \\
\text { the situation of disrespect with an activity that was meaningful for all } \\
\text { students, trying to make everyone understand that such action was not } \\
\text { well seen in the class. }\end{array}$ \\
\hline & $\begin{array}{l}\text { Punitive } \\
\text { control }\end{array}$ & $\begin{array}{l}\text { During this visit, the students were always very receptive and } \\
\text { participative, and the teacher used an appropriate tone of voice during the } \\
\text { course of the activity, being very natural in the development of this } \\
\text { activity. }\end{array}$ \\
\hline & $\begin{array}{l}\text { Sarcasm and } \\
\text { respect }\end{array}$ & $\begin{array}{l}\text { During the development of the activity the teacher does not show to be } \\
\text { sarcastic or humiliating with the students, on the contrary, the teacher } \\
\text { handles conflict situations in a calm and serene manner, seeking to have } \\
\text { a good climate in the classroom. }\end{array}$ \\
\hline & $\begin{array}{l}\text { Severe } \\
\text { negativity }\end{array}$ & $\begin{array}{l}\text { The educator does not use physical punishment or intimidation with any } \\
\text { of the students. }\end{array}$ \\
\hline
\end{tabular}


TABLE 6

CLASS RESULTS PRIVATE INSTITUTION: LITERATURE CLASS

\begin{tabular}{|c|c|c|}
\hline \multirow{4}{*}{$\begin{array}{l}\text { Positive } \\
\text { climate }\end{array}$} & Relationship & $\begin{array}{l}\text { The teacher shows a little more physical contact with the children, } \\
\text { although it is not very strong and constant, not having preference } \\
\text { with any of the students; in the reading activity; it was evident that } \\
\text { some of the students were tired in the proposed activity, getting } \\
\text { distracted very easily, although this is not present in all of them. }\end{array}$ \\
\hline & Positive affect & $\begin{array}{l}\text { Neutral with the students, the teacher was not affectionate with } \\
\text { them, although there were some smiles with all the children, } \\
\text { expressing in this way that there was no special preference for any } \\
\text { child, it was also evident that the students enjoyed the activity, } \\
\text { showing themselves comfortable and happy with the proposed } \\
\text { activity. }\end{array}$ \\
\hline & Sarcasm/disrespect: & $\begin{array}{l}\text { Interacts with the students in the development of the narrated } \\
\text { story, makes them participate in it, shows great interest in the } \\
\text { answers they make, praises them and makes them feel that their } \\
\text { opinion is worth, making everyone present be attentive to the child } \\
\text { who has the floor. }\end{array}$ \\
\hline & Respect & $\begin{array}{l}\text { A great respect was shown for the students, since the teacher } \\
\text { addressed them by their proper name and looked them in the face } \\
\text { when they engaged in conversation with them, likewise, when a } \\
\text { student speaks, the others pay attention and if any of them is } \\
\text { distracted, the teacher asks them to pay attention to the } \\
\text { contribution made by the student. }\end{array}$ \\
\hline \multirow[t]{4}{*}{$\begin{array}{l}\text { Teacher } \\
\text { sensitivity }\end{array}$} & Awareness & $\begin{array}{l}\text { The teacher is attentive to the students' understanding of the story } \\
\text { proposed by the teacher, constantly asks questions of the story to } \\
\text { verify their concentration, if any of the students does not have the } \\
\text { correct answer, they are supported by another classmate, at the end } \\
\text { of the narration of the story the teacher makes notes on the board } \\
\text { highlighting the teaching left by the story. }\end{array}$ \\
\hline & Response capacity & $\begin{array}{l}\text { The narration of the story also showed that occasionally the } \\
\text { teacher ignored some comments from the students, although it } \\
\text { happened very spontaneously, disregarding the emotion with } \\
\text { which the child expresses this contribution; but during the } \\
\text { development of the narration of the book the vast majority of the } \\
\text { children were excited, participatory and the teacher tried to } \\
\text { capture the coherent comments of almost all the students. }\end{array}$ \\
\hline & Addresses problems & $\begin{array}{l}\text { It is evident that in the development of the activity, in the case of } \\
\text { students who were unable to answer the questions proposed by the } \\
\text { teacher, the educator tried to rely on other students, thus trying to } \\
\text { make the students more attentive and be able to solve their lack of } \\
\text { knowledge of the subject. }\end{array}$ \\
\hline & Student comfort & $\begin{array}{l}\text { They were comfortable in the development of the activity, they } \\
\text { participated freely proposing ideas and making contributions to } \\
\text { the narration of the story, and the teacher highlighted the } \\
\text { contributions made by the students, letting them know that their } \\
\text { opinion is important for the development of the class. }\end{array}$ \\
\hline
\end{tabular}




\section{Phase 3. Formulation of the General Plan: Didactic Strategies}

According to the review of the documentary base established from the lines of teaching science and literature from the context of early childhood education, it was possible to differentiate the criteria for the design of a didactic proposal for the teaching of the aforementioned lines of study. For this purpose, the analysis of the data obtained in the recognition phase using the CLASS instrument that evaluated the classroom climate (positive-negative) evidenced in the two I.E. was considered. The didactic sequences for the teaching of science were proposed taking into account the model structure proposed by Feo (2010.p. 231) identifying three sequential moments transversalized by an evaluation moment: 1) beginning moment: attentional activator, established purpose, interest generator and previous ideas; 2) development moment: information processing, focused attention and defined teaching strategies framed in the learning processes proper to the age, the context and the strategies found in the documentary review: living organisms workshops, the human body and the properties of water, graphic representations and observation of nature, multisensory experiences, oral presentations, ecological garden, inquiry activities, ICT applied to science teaching, molding, stories and tales related to the exploration of the environment, ecological laboratories, recycling workshops and science corner; 3) closing moment: review, synthesis of what was learned, transfer of knowledge through results and evidence of learning, emotional reinforcement and closure. In this order of ideas, the literature line designed a proposal from the need to reflect on the canon established from the curriculum, this first critical reading is assumed from the need to explore the new literary works that have been written in the last period, all with the aim of establishing a dialogue with the literary tradition, that is, the look at the canon sought a reflection and update, there, it is expected, the first achievement of this didactic design. Following the above and based on the results of the CLASS instrument, the activities designed explored genres such as audio stories, album books, stories and children's novels in order to reconstruct the educational practices from a language that links the student's voice and their experiences, since the virtue of the didactic proposal lies in the transformation of the discourse so that it communicates the immediate realities of the subjects. In this order, the linking of new literatures and activities that move away from the instrumental vision of the literary work, to give it a primordial place in the teaching-learning relationship was made possible

\section{ANALYSIS AND DISCUSSION OF THE RESULTS}

It was determined that there is a low tendency of academic literature on science education in preschool at present. There is a strong tendency towards the development of children's scientific thinking and its characteristics, as well as strong tendencies towards meaningful, contextual and explanatory learning, as well as the need for innovation and the use of Information and Communication Technologies. The results obtained by means of the characterization of the emotional support of the teachers of the institutions (private and public) of the city of Ibagué were established criteria that contemplates the observation instrument CLASS and supported with video feedback as part of the process of the observation intervention, as an evaluation system focused on assessing the quality of teacher-child interactions in the classroom, showed that in most cases, warm and supportive relationships were maintained with the students, at a general level, the interactions were positive in terms of communication and positive affection; the good use of respect between teacher-student and between peers was highlighted.

\section{CONCLUSIONS}

The documentary review makes it possible to determine a baseline to generate proposals for teaching science and literature in early childhood education articulated to the trends and school climate in the classroom. Educators have a primordial role in the development of children in early childhood, they must promote self-esteem, respect, and reinforce the development of social skills, and create learning environments that strengthen school performance, this is what the teachers of the educational institutions

Rafael García Herreros and José Joaquín Flórez must propose in their classrooms with the objective of building affective and positive relationships taking into account their approach and their lives to connect 
them with the teaching processes and their significant learning. The CLASS demonstrates that in order to obtain a positive advance in the student-teacher correspondence it is of vital importance to involve the mechanism of affection and communication to obtain bilateral understanding, interpersonal insight and empathy, having as a fundamental basis that affection or attachment, always preserves an inseparable correspondence with knowledge. The observations presented in this publication give an exploratory look at the particularities of didactics in two institutions, one private and one public. The results show, in the first place, that the two teachers have emotional support with their students, even if these are not too overt, likewise a comparison can be made of what teachers do from two different points of view, since each educator showed similar positions, but not the same, showing their confrontation between their pedagogical discourse and actions.

\section{ACKNOWLEDGEMENT}

Translated \& edited by American Publishing Services (https://americanpublishingservices.com/).

\section{REFERENCES}

Berlin, L.J., \& Cassidy, J. (1999). Relations among relationships: Contributions from attachment theory and research. In J. Cassidy \& P.R. Shaver (Eds.), Handbook of attachment: Theory, research, and clinical applications (pp. 688-712). The Guilford Press.

Bowlby, J. (1969). Attachment and loss. Nueva York: Basic Books.

Cárdenas Páez, A. (2009). Literatura, pedagogía y formación en valores. Enunciación, 14(2), 5-20.

Castaño, C., Martín, J., \& Martínez, J.L. (2011). La brecha digital de género en España y Europa: Medición con indicadores compuestos. Revista Española de Investigaciones Sociológicas, 136, 127-140. https://doi.org/10.5477/cis/reis. 136.127

Colomer, T. (2005). Andar entre libros: La lectura literaria en la escuela. Fondo de cultura Económica con énfasis en Literatura, E. Arqueología de la enseñanza de la literatura en la educación colombiana desde la formación humanística1.

Duque, A., \& Ovalle, P. (2011). La interacción en el aula: Una vía para posibilitar la comprensión inferencial de textos narrativos en niños de preescolar. Psicología y Disciplina, 5(2), 1-11.

Feo Mora, R.J. (2010). Orientaciones básicas para el diseño de estrategias didácticas. Tendencias Pedagógicas, (16), 221-236.

Knudsen, E.I., Heckman, J.J., Cameron, J.L., \& Shonkoff, J.P. (2006). Economic, neurobiological, and behavioral perspectives on building America's future workforce. Proceedings of the National Academy of Sciences, 103(27), 10155-10162.

McMillan, J., \& Schumacher. S. (2005). Investigación educativa (5.a edición). Madrid. PEARSON EDUCACIÓN, S. A.

Ministerio de educación Nacional [MEN]. (2017). De cero a siempre. Atención integral a la primera infancia.

Páez, A.C. (2009). Literatura, pedagogía y formación en valores. Enunciación, 14(2), 5-20.

Parra, C. (n.d.). Investigación acción y desarrollo profesoral. Educación y Educadores, (5), 113-125.

Ruiz, P.G., \& Valero, A.L. (1993). La literatura infantil y su didáctica. Revista Interuniversitaria de Formación del Profesorado, (18), 187-199.

Salinas-Quiroz, F., Mihalfi, V.C., \& Cabrera, P.S. (2016). Aportes ecológico-interactivos a la psicología educativa. Revista Puertorriqueña de Psicología, 26(1), 26-37. 